\title{
LIFETIME PADA PIPA GAS LURUS Ø 14" MENGGUNAKAN METODE RISK BASED INSPECTION BERASARKAN API 581
}

\author{
Gunawan Dwi Haryadi $^{1 *}$, Ismoyo Haryanto ${ }^{1}$, Dwi Basuki Wibowo ${ }^{1}$, \\ Agus Suprihanto ${ }^{1}$
}

\begin{abstract}
ABSTRAK
Korosi terjadi tanpa mengenal waktu di segala aspek kehidupan manusia dan dapat mengakibatkan banyak kerugian. Di industri minyak dan gas, kerugian yang terjadi akibat korosi berdampak pada penurunan kualitas material yang digunakan. Dua hal ini berarti berhubungan dengan lamanya operasional alat berfungsi atau kemampuan jangka panjang dari suatu alat dan kemungkinan terjadinya kegagalan pada peralatan yang digunakan. Sehingga jika korosi menyerang, maka selain kerugian finansial yang dialami. Sehingga jika korosi menyerang maka selain kerugian finansial yang dialami, kerugain juga berdampak terhadap lingkungan sekitar dan juga safety dari pekerja dan masyarakat sekitar juga bisa terjadi. Oleh karena itu inspeksi terhadap peralatan yang ada penting untuk dilakukan. Indonesia yang masih mengacu pada inspeksi berdasarkan jangka waktu (time based inspection) masih memberikan peluang untuk terjadinya kegagalan pada peralatan yang digunakan. Oleh karena itu penting untuk menggunakan acuan lain seperti inspeksi berdasarkan tingkat risiko (Risk-Based Inspection)/RBI.

Hasil penelitian menunjukan bahwa dari pipeline yang dianalisa yakni berdiameter 14" dengan lama penggunaan 8 tahun memiliki nilai 1C yang berarti berstatus risiko low medium dan mendapatkan respon corrective maintenance. Usulan inspeksi yang dapat dilakukan adalah pemeriksaan visual, ultrasonic straight beam, eddy current, flux leakage, radiography, dan pengukuran dimensi. Usulan waktu inspeksi yang dapat dilakukan kembali adalah 3 tahun kemudian. Nilai rendah yang diperoleh melalui penelitian ini dikarenakan pipa memiliki system inspeksi yang baik sehingga nilai TMSF tidak mengalami pertambahan yang signifikan
\end{abstract}

Kata kunci: Korosi, RBI, Risk-Based Inspection, pipping

\section{PENDAHULUAN}

Jaringan pipa gas alam adalah bagian yang penting dari infrastruktur kota untuk transmisi energi. Dengan perkembangan kota modern, gas alam saat ini telah menjadi salah satu sumber yang paling banyak digunakan sebagai sumber energi. Namun, dengan jaringan

\footnotetext{
${ }^{1}$ Departemen Teknik Mesin Universitas Diponegoro, Indonesia

*Corresponding author:

e-mail: gunawan_dh@undip.ac.id
} 
pipa gas yang mulai berkembang dan lebih kompleks, kecelakaan yang disebabkan oleh kebocoran jaringan pipa gas dapat terjadi. Konsekuensi kecelakaan yang disebabkan oleh pipa gas yang rusak akan menyebabkan kebakaran dan ledakan, sehingga langsung mengancam keselamatan masyarakat dan harta benda (Menteri Pertambangan dan Energi Republik Indonesia, 1997).

Jika terjadi kecelakaan, banyaknya penduduk perkotaan dan padatnya bangunan cenderung menyulitkan evakuasi warga, dengan demikian mengakibatkan kerugian besar nyawa dan harta benda. Dalam beberapa tahun terakhir, banyak kecelakaan gas alam telah terjadi di rumah warga dan negara-negara lain (Barjono, R.R.A., 2010). Oleh karena itu, untuk mencegah kecelakaan dan mengurangi kerusakan akibat kecelakaan tersebut, perlu untuk mengusulkan kerangka penilaian analisis risiko yang sistematis untuk jaringan pipa gas alam. Seperti kerangka yang membantu memprediksi luas daerah kecelakaan gas alam yang mungkin terjadi dan kemungkinan dampak terhadap pekerja dan masyarakat kebocoran pipa gas alam sehingga penyelamatan dapat dilakukan (Barjono, R.R.A., 2010).

Risk Based Inspection (RBI) merupakan suatu metode yang erat hubungannya dengan pembahasan risk assesment. Metode ini menggunakan risiko sebagai dasar untuk memprioristaskan dan mengelola program inspeksi. Metodologi Risk Based Inspection ini memungkinkan pengoptimalan sumber daya inspeksi dan pemeliharaan pada daerah yang mempunyai risiko tinggi. Selain itu, Risk Based Inspection merupakan pengoptimalan kombinasi dari metode inspeksi peralatan, cakupan inspeksi, dan frekuensi. Adapun tujuan dilakukan Risk Based Inspection adalah:

a. Mengidentifikasi daerah yang tergolong dalam klasifikasi berisiko tinggi.

b. Mengestimasi besarnya nilai risiko yang ada pada setiap peralatan saat operasi berdasarkan metodologi yang konsisten.

c. Memprioritaskan peralatan berdasarkan pengukuran besarnya risiko.

d. Melakukan perencanaan dan perancangan program inspeksi yang tepat.

\section{METODOLOGI}

\section{Risk-Based Inspection (RBI)}

Risk Based Inspection (RBI) merupakan salah satu metode yang relatif baru dalam melakukan suatu inspeksi. Metode ini berdasarkan analisis risiko yaitu meliputi mengenai analisis besarnya kemungkinan munculnya suatu kegagalan dan besarnya efek risiko yang muncul akibat kegagalan tersebut dan hubungannya terhadap sistem operasi yang sedang 
berjalan (Noori \& Price, 2006). Risk-Based Inspection (RBI) adalah metode inspeksi berbasis risiko dimana bahaya sebagai dasar untuk memprioritaskan dan sebagai upaya mengelola program inspeksi. Dalam pabrik yang sedang beroperasi, persentase relatif besar yang terkait risiko dari item peralatan. RBI memungkinkan pergeseran inspeksi dan pemeliharaan sumber daya untuk menyediakan tingkat keamanan yang lebih tinggi dari cakupan pada item yang berisiko tinggi dan upaya yang akan dikerjakan dengan peralatan yang baik agar risiko bahaya tersebut menjadi lebih rendah. Manfaat potensial dari program RBI adalah untuk meningkatkan waktu operasi peralatan dan menjalankan fasilitas industri dengan proses yang panjang agar kegagalan dapat diminimalisasi atau setidaknya mempertahankan pada tingkat risiko yang sama (API, 2008).

Metode RBI mendefinisikan risiko peralatan operasi sebagai kombinasi dari dua parameter terpisah yaitu perkalian dari konsekuensi kegagalan dan kemungkinan kegagalan. Sehingga menurut RBI risiko didefinisikan seperti pada persamaan 1. Sedangkan konsep RBI secara umum di lihat pada Gambar 1. Penerapan metode RBI dapat menekan biaya belanja tetap perusahaan pada pos biaya perawatan peralatan berbasis waktu (time based).

$$
\text { Risk }=\mathrm{CoF} \times \mathrm{PoF}
$$

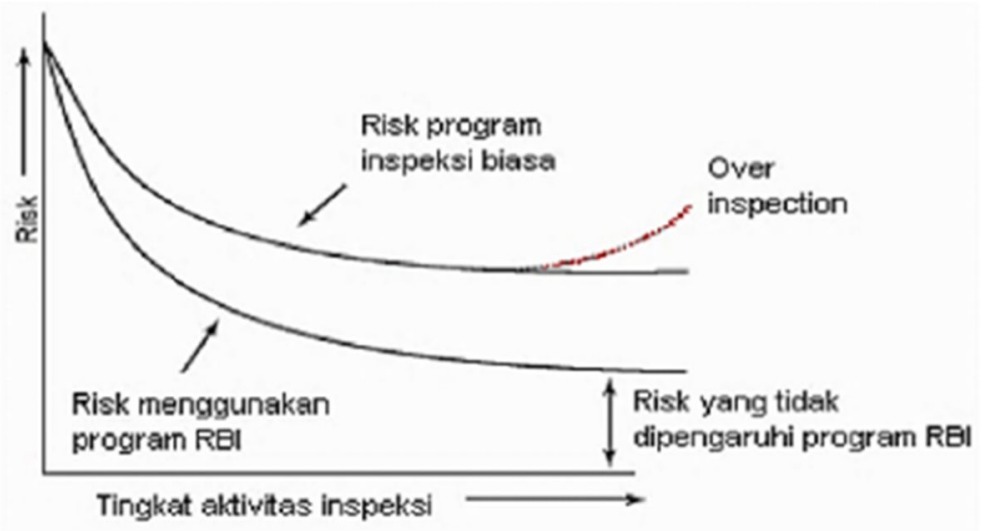

Gambar 1. Konsep manajemen Risk Based Inspection secara Umum

(Perumal, 2014)

\section{Consequence of Failure (CoF)}

Definisi consequence of failure pada kajian risiko pipeline adalah konsekuensi atau akibat negatif yang diterima akibat kegagalan pipeline. Pada metode indeks, Nilai CoF diwakili oleh Leak Impact Factor (LIF). Semakin tingginya nilai LIF maka semakin tinggi pula konsekuensi dalam suatu sistem, dimana semakin tinggi konsekuensi maka resikonya juga semakin tinggi. Besar LIF dipengaruhi oleh empat faktor utama, yaitu tingkat ancaman dari produk (product hazard), banyaknya volume yang terlepas jika ada kebocoran (leak volume), 
jangkauan relatif dari kebocoran (dispersion), dan lingkungan disekitarnya yang menerima produk yang terlepas (receptors) (Prayoga, 2015).

$$
\mathrm{LIF}=\mathrm{PH} \times \mathrm{LV} \times \mathrm{D} \times \mathrm{R}
$$

Keterangan:

$$
\begin{array}{ll}
\text { LIF } & =\text { Leak Impact Factor } \\
P H & =\text { Product Hazard } \\
L V & =\text { Leak Volume } 23 \\
D & =\text { Dispersion } \\
R & =\text { Receptors }
\end{array}
$$

Analisa konsekuensi kegagalan akibat terlepasnya fluida representatif pada metode semi-kuantitatif RBI terdiri dari atas dua bagian, yaitu: konsekuensi akibat terlepas fluida yang mudah terbakar dan konsekuensi akibat terlepasnya fluida yang beracun. Pada kasus analisa tingkat resiko pada masing - masing peralatan yang diamati, fluida representatif yang terdapat di dalamnya hanya mempunyai sifat mudah terbakar.

Nilai konsekuensi kebakaran didapatkan dari luas daerah akibat kebocoran yang terdiri dari luas daerah akibat kebocoran yang terdiri atas luas derah kerusakan dan luas derah berbahaya. Dari kedua jenis luas itu dipilih nilai yang paling besar kemudian dikalikan dengan nilai fraksi kerusakan generik dan didapatkan luas daerah konsekuensi kegagalan. Luas daerah kegagalan total dapat dicari dengan menjumlahkan luas kebocoran dari setiap lubang, karena luas daerah suatu kebocoran diakibatkan dari kebocoran dari setiap lubang.

\section{Menghitung Laju Kebocoran}

Untuk mempermudah analisis perhitungan frekuensi kegagalan sehingga tidak diperlukan perhitungan setiap ukuran lubang, ukuran lubang disederhanakan yakni smal, medium, large, dan rupture seperti Tabel 1.

Tabel 1. Ukuran Lubang dalam API 581(API,2008)

\begin{tabular}{|l|l|l|}
\hline Jenis lubang & $\begin{array}{l}\text { Diameter } \\
\text { lubang }\end{array}$ & $\begin{array}{l}\text { Diameter lubang pelepasan (release), } \\
\left(\mathrm{d}_{\mathrm{n}}\right) \text { representatif }\end{array}$ \\
\hline Kecil $($ small $)$ & $0 \mathrm{~s} / \mathrm{d} 1 / 4$ in & $1 / 4$ in \\
\hline Sedang (medium) & $1 / 4-2$ in & 1 in \\
\hline Besar (large) & $2-6$ in & 4 in \\
\hline Pecah (rupture) & $>6$ in & Diameter equipment, maksimum 12 in \\
\hline
\end{tabular}


Untuk menghitung laju kebocoran, kita harus mengetahui fasa fluida yang terdapat dalam pressure vessel. Apabila fasanya berupa gas, maka digunakan persamaan untuk menghitung laju kebocoran gas dan apabila fasanya cair digunakan persamaan laju kebocoran liquid. Untuk menghitung laju kebocoran fluida yaitu dengan menggunakan persamaan yang terdapat pada API BRD 581.

Setelah diketahui laju kebocorannya, selanjutnya adalah menghitung durasi kebocoran pressure vessel dari jumlah (kapasitas) total fluida yang disimpan di dalamnya. Kemudian dianalisa jenis aliran kebocorannya, apakah termasuk jenis aliran yang kontinyu atau seketika. Sesuai dengan metode RBI, untuk menentukan jenis aliran kebocoran yaitu dengan menghitung aliran massa yang keluar dalam waktu 3 menit. Jika dalam waktu 3 menit aliran massa yang keluar melebihi $10.000 \mathrm{lbs}$, maka aliran tersebut dikategorikan ke dalam aliran seketika dan demikian sebaliknya. Pada perhitungan di atas, tampak bahwa untuk ukuran lubang $1 / 4$ inch dan 1 inch adalah aliran kontinyu sedangkan untuk ukuran lubang 4 inch dan 16 inch adalah aliran seketika.

Tahap akhir dari ini adalah membandingkan antara estimasi durasi kebocoran sesuai sistem deteksi dan sistem isolasi dengan waktu kebocoran sebenarnya. Untuk aliran seketika dianggap 0 menit, sedangkan untuk aliran kontinyu dibandingkan dan dicari yang terkecil, yang kemudian dijadikan sebagai durasi kebocoran.

\section{Probability of Failure (PoF)}

Probabilitas kegagalan adalah kemungkinan suatu peralatan atau komponen mengalami gagal (API, 2008). Analisis terjadinya suatu kegagalan dalam komponen tersebut yang akan dianalisis adalah apabila berada dalam kondisi kerja saat ini. Persamaan probabilitas kegagalan dalam API RBI adalah (Prayoga, 2015):

$$
\operatorname{Pf}(\mathrm{t})=\mathrm{gff} . \mathrm{Df}(\mathrm{t})
$$

$\operatorname{Pf}(\mathrm{t}) \quad=$ Probabilitas kegagalan (probability of failure)

gff $\quad=$ Frekuensi kegagalan suatu komponen (generic failure frequency)

$\operatorname{Df}(\mathrm{t}) \quad=$ Faktor kerusakan (damage factor)

Analisa peluang kegagalan pada peralatan yang diamati, dengan metode semi kuantitatif RBI dilakukan melalui proses TMSF (Technical Modules Sub-Factor) untuk setiap mekanisme kerusakan yang dialaminya. Mekanisme kerusakan yang dialami untuk setiap peralatan dapat ditentukan melalui pemindaian pada kondisi operasi peralatan tersebut. TSMF yang dipakai dalam analisa kerusakan terdiri dari beberapa mekanisme kerusakan yang dapat 
terjadi oleh sebuah peralatan karena kondisi operasi maupun jenis fluida yang bekerja. Mekanisme kerusakan yang terdapat pada TMSF RBI adalah :

\section{TMSF Thinning}

2. TMSF SCC (Stress Corrosion Cracking)

3.TMSF HTHA (High Temperature Hydrogen Attack)

4. TMSF Furnace Tube

5. TMSF Mechanical Fatique

6. TMSF Brittle Fracture

7. TMSF Linning

8. TMSF External Damage

Dalam peralatan pressure vessel ini hanya faktor thinning yang memiliki kemungkinan disebabkan oleh fluida servis yang berada di dalamnya yang berupa $\mathrm{C} 1-\mathrm{C} 2$, C3-C4, dan C6C8.

\section{Martiks Resiko}

Hasil analisa RBI pada masing-masing pressure vessel menunjukkan kategori resiko. Resiko didapatkan dengan mengkombinasikan besar likelihood dan consequence category terhadap matriks resiko 5x5 yang telah disediakan oleh API pada low risk dan 14 buah pressure vessel lainnya berada pada medium risk.
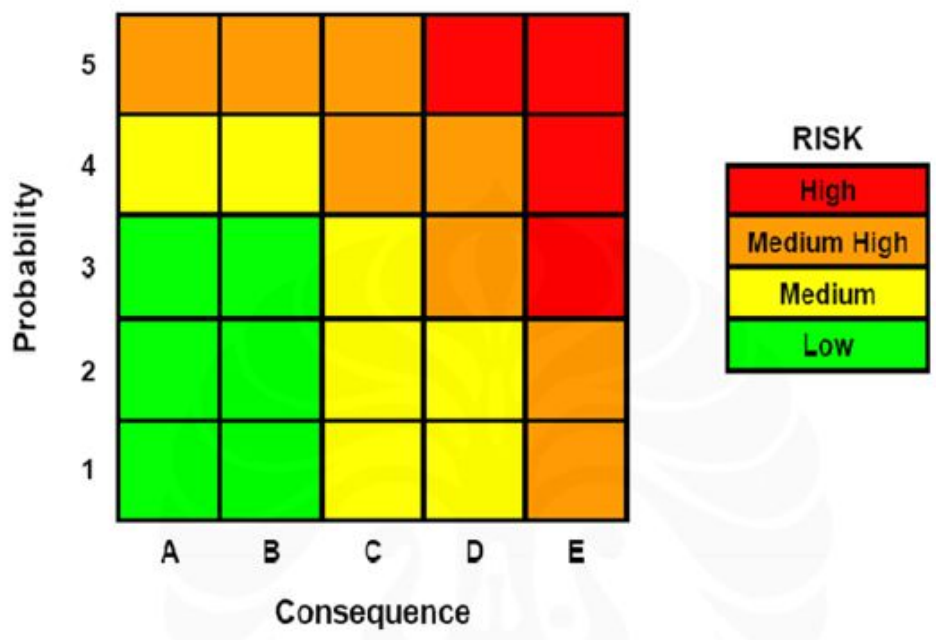

Gambar 2. Matriks Resiko (API,2008)

\section{HASIL DAN PEMBAHASAN}

Analisis RBI berdasarkan metode semi kuantitatif dapat dihitung dengan berpedoman pada Appendix B-Workbook for Semi-Quantitative Risk Based Inspection Analysis API RBI 
581. Terdapat lima lembar kerja pada buku kerja tersebut yaitu Bagian A, Bagian B, Bagian C1, Bagian C2 dan Bagian D. Kelima lembar kerja tersebut yang nantinya akan membantu untuk menghitung konsekuensi kegagalan dan kemungkinan kegagalan sehingga didapatkan nilai resiko.

Tabel 2. Data Inspeksi

\begin{tabular}{|c|c|c|c|c|}
\hline \multirow[b]{2}{*}{ No } & \multirow[b]{2}{*}{ Jenis Pipa } & \multicolumn{2}{|c|}{ Ketabalan Pipa (in) } & \multirow{2}{*}{$\begin{array}{c}\text { Tebal Awal } \\
\text { (in) dengan } \\
\text { coating }\end{array}$} \\
\hline & & Inspeksi & $\begin{array}{l}\text { Tanpa } \\
\text { Coating }\end{array}$ & \\
\hline 1 & $\begin{array}{l}\text { Pipa Gas Lurus KP 09+012 } \\
\text { 14" }\end{array}$ & 0,305 & 0,255 & 0,344 \\
\hline 2 & $\begin{array}{l}\text { Pipa Gas Lurus KP } 15+110 \varnothing \\
14 "\end{array}$ & 0,306 & 0,256 & 0,344 \\
\hline 3 & $\begin{array}{l}\text { Pipa Gas Lurus KP 19+040 Ø } \\
14 "\end{array}$ & 0,305 & 0,255 & 0,344 \\
\hline
\end{tabular}

\section{Analisis PoF}

Dalam menganilis sebuah peralatan yang berukuran besar maka peralatan tersebut dibagi menjadi beberapa bagian, hal ini dilakukan karena dalam proses pemurnian kondisi fluida dalam peralatan berbeda pada setiap bagiannya (Nayyar M, 2000). Sehingga untuk menganalisis TMSF agar lebih terkontrol maka production separator dibagi menjadi beberapa bagian, hal ini dikarenakan perbedaan corrosion rate dari setiap bagian. Pembagian seperti ditunjukkan pada Gambar 1. Peralatan yang dianalisis kali ini merupakan pressure vessel. Berdasarkan API RBI 581 TMSF yang terjadi adalah thinning disebabkan adanya korosi setempat (localized) oleh faktor fluida yang dikandung. Untuk mendapatkan nilai dari TMSF Thinning perlu untuk dicari terlebih dahulu konstanta reduksinya. Dalam mencari konstanta reduksi dipakai persamaan di bawah:

$$
\text { a. } \mathrm{r} / \mathrm{t}
$$

Dimana:

$$
\begin{aligned}
& \mathrm{a}=\text { Lama Pemakaian (Tahun) } \\
& \mathrm{r}=\text { Corrosion Rate (mm/year) } \\
& \mathrm{t}=\text { Tebal }(\mathrm{mm})
\end{aligned}
$$


Tabel 3. Konstanta Reduksi Ketebalan

\begin{tabular}{|c|c|c|c|c|c|c|c|c|}
\hline \multirow{2}{*}{ No. } & \multirow{2}{*}{ Komponen } & \multicolumn{2}{|c|}{ Thickness } & \multirow{2}{*}{$\begin{array}{c}\text { Usia } \\
\text { (tahun) }\end{array}$} & \multirow{2}{*}{$\mathrm{T}_{0 \text { (in) }}$} & \multirow{2}{*}{$\begin{array}{c}\mathrm{Cr} \\
\text { (in/tahun) }\end{array}$} & \multirow{2}{*}{$\mathrm{CA}$} & \multirow{2}{*}{ Art } \\
\hline & & $T_{\text {actual (in) }}$ & $T_{\min (\mathrm{in})}$ & & & & & \\
\hline 1 & $\begin{array}{l}\text { Pipa Gas Lurus KP } \\
09+012 \text { Ø } 14 "\end{array}$ & 0,255 & 0,176 & 8 & 0,344 & 0,005 & 0,118 & 0,2645 \\
\hline 2 & $\begin{array}{l}\text { Pipa Gas Lurus KP } \\
15+110 \emptyset 14^{\prime \prime}\end{array}$ & 0,255 & 0,176 & 8 & 0,344 & 0,005 & 0,118 & 0,2618 \\
\hline 3 & $\begin{array}{l}\text { Pipa Gas Lurus KP } \\
19+040 \text { ø } 14^{\prime \prime}\end{array}$ & 0,255 & 0,176 & 8 & 0,344 & 0,005 & 0,118 & 0,2619 \\
\hline
\end{tabular}

Efektifitas inspeksi alat tergolong dalam fairly effective dikarenakan pengukuran ketebalan telah dilakukan dengan metode Spot Ultrasonic Test (UT) dan pemeriksaan visual namun tanpa adanya pelepasan bagian alat. Selama pemakaian, production separator telah dilaksanakan dua kali inspeksi yaitu pada tahun 2010 dan 2013. Sehingga dari nilai konstanta reduksi dan efektifitas inspeksi didapatkan nilai TMSF. Namun sebelum menentukan termasuk ke dalam kategori kemungkinan kegagalan yang mana, masih perlu dilakukan penghitungan TMSF Adjust. TMSF Adjust didapatkan dengan mengalikan nilai TMSF dengan nilai faktor overdesign. Nilai faktor overdesign sendiri didapatkan dengan melihat rasio Maximum Allowable Work Pressure (MAWP) dengan Operational Pressure (OP) dan didapatkan bahwa faktor overdesign dari alat tersebut adalah 0.5. Sehingga didapatkan kategori kegagalan seperti pada Tabel 4.

Tabel 4. Kategori TMSF

\begin{tabular}{|c|l|c|c|c|c|c|}
\hline No. & \multicolumn{1}{|c|}{ Komponen } & $\begin{array}{c}\text { Base } \\
\text { Demage } \\
\text { Factor }\end{array}$ & $F_{O M}$ & $F_{I P}$ & $F_{D L}$ & $\begin{array}{c}\text { Damage Factor } \\
\text { Thinning }\end{array}$ \\
\hline 1 & $\begin{array}{l}\text { Pipa Gas Lurus KP } \\
09+012 \text { Ø 14" }\end{array}$ & 164,4 & 1 & 1 & 1 & 164,4 \\
\hline 2 & $\begin{array}{l}\text { Pipa Gas Lurus KP } \\
15+110 \text { Ø 14" }\end{array}$ & 161,8 & 1 & 1 & 1 & 161,8 \\
\hline 3 & $\begin{array}{l}\text { Pipa Gas Lurus KP } \\
19+040 \varnothing 14 ”\end{array}$ & 161,9 & 1 & 1 & 1 & 161,9 \\
\hline
\end{tabular}

\section{Analisa CoF}

Berdasarkan data yang didapatkan tekanan operasi, fase fluida representatif, dan temperatur proses dilihat dari tingkat keadaan fluida kerja di dalam peralatan yang diamati dapat dilihat pada Tabel 5 . 
Tabel 5. Data Operasi Pipa

\begin{tabular}{|c|c|c|c|c|c|}
\hline \multirow{2}{*}{ No. } & Komponen & \multicolumn{4}{|c|}{ Data proses } \\
\cline { 3 - 6 } & $\begin{array}{c}\text { P.design } \\
(\mathrm{psig})\end{array}$ & $\begin{array}{c}\text { P. opr. } \\
(\mathrm{psig})\end{array}$ & $\begin{array}{c}\text { T.design } \\
\left({ }^{\circ} \mathrm{F}\right)\end{array}$ & $\begin{array}{c}\text { T.opr. } \\
\left({ }^{\circ} \mathrm{F}\right)\end{array}$ \\
\hline 1 & Pipa Gas Lurus KP 09+012 Ø 14" & 1344,5 & 1029,7 & 212 & 156,2 \\
\hline 2 & Pipa Gas Lurus KP 15+110 Ø 14" & 1344,5 & 1029,7 & 212 & 156,2 \\
\hline 3 & Pipa Gas Lurus KP 19+040 Ø 14" & 1344,5 & 1029,7 & 212 & 156,2 \\
\hline
\end{tabular}

Dari data operasional pipa maka dapat ditentukan jenis aliran dan nilai Release rate jika terjadi kebocoran, hasilnya dapat dilihat pada Tabel 6.

Tabel 6. Nilai Release Rate

\begin{tabular}{|c|c|c|c|c|c|c|c|c|c|}
\hline \multirow{2}{*}{ No. } & \multirow{2}{*}{ Komponen } & \multirow{2}{*}{ Fase } & \multirow{2}{*}{$P_{\text {tress }}$} & \multirow{2}{*}{$P_{\text {opperation }}$} & \multirow{2}{*}{$\begin{array}{l}\text { Jenis } \\
\text { Aliran }\end{array}$} & \multicolumn{4}{|c|}{$\begin{array}{c}\text { Nilai Release Rate Wn } \\
\qquad(\mathrm{lb} / \mathrm{s})\end{array}$} \\
\hline & & & & & & $1 / 4$ in & 1 in & 4 in & rupture \\
\hline 1. & $\begin{array}{l}\text { Pipa Gas Lurus KP 09+012 Ø } \\
14 "\end{array}$ & Gas & 24,873 & 212 & Sonic & 2,86061 & 45,76976 & 732,3162 & 6590,846 \\
\hline 2. & $\begin{array}{l}\text { Pipa Gas Lurus KP } 15+110 \varnothing \\
14 "\end{array}$ & Gas & 24,873 & 212 & Sonic & 2,86061 & 45,76976 & 732,3162 & 6590,846 \\
\hline 3. & $\begin{array}{l}\text { Pipa Gas Lurus KP 19+040 Ø } \\
14 "\end{array}$ & Gas & 24,873 & 212 & Sonic & 2,86061 & 45,76976 & 732,3162 & 6590,846 \\
\hline & & & & & & & & & \\
\hline
\end{tabular}

Berdasarkan API 581 penentuan kondisi sistem deteksi dan sistem isolasi dapat menentukan persentase reduksi laju kebocoran atau massa yang dapat keluar, dimana persentase reduksinya yaitu $25 \%$. Sehingga laju kebocoran setelah direduksi untuk setiap lubang kebocoran pada setiap peralatan yang dianalisis dapat dilihat pada Tabel 7 .

Tabel 7. Laju Kebocoran Setelah Reduksi 25\%

\begin{tabular}{|c|c|c|c|c|}
\hline No. & Komponen & $\begin{array}{l}\text { Ukuran } \\
\text { lubang }\end{array}$ & $\begin{array}{c}\text { Laju } \\
\text { Kebocoran }\end{array}$ & $\begin{array}{c}\text { Laju } \\
\text { Kebocoran } \\
\text { Setelah } \\
\text { Direduksi }\end{array}$ \\
\hline \multirow{4}{*}{1} & \multirow{4}{*}{$\begin{array}{l}\text { Pipa Gas Lurus KP 09+012 } \\
\text { Ø 14” }\end{array}$} & $1 / 4$ in & 2,860610118 & 2,145457588 \\
\hline & & 1 in & 45,76976188 & 34,32732141 \\
\hline & & 4 in & 732,3161902 & 549,2371426 \\
\hline & & rupture & 6590,845711 & 4943,134284 \\
\hline \multirow{4}{*}{2} & \multirow{4}{*}{$\begin{array}{l}\text { Pipa Gas Lurus KP } 15+110 \\
\text { Ø 14" }\end{array}$} & $1 / 4$ in & 2,860610118 & 2,145457588 \\
\hline & & 1 in & 45,76976188 & 34,32732141 \\
\hline & & 4 in & 732,3161902 & 549,2371426 \\
\hline & & rupture & 6590,845711 & 4943,134284 \\
\hline \multirow{4}{*}{3} & \multirow{4}{*}{$\begin{array}{l}\text { Pipa Gas Lurus KP 19+040 } \\
\text { Ø 14" }\end{array}$} & $1 / 4$ in & 2,860610118 & 2,145457588 \\
\hline & & 1 in & 45,76976188 & 34,32732141 \\
\hline & & 4 in & 732,3161902 & 549,2371426 \\
\hline & & rupture & 6590,845711 & 4943,134284 \\
\hline
\end{tabular}


Sistem mitigasi yang digunakan pada setiap stasiun pipa gas yaitu inventory blowdown dengan menggabungkan sistem isolasi $\mathrm{B}$ atau lebih tinggi, maka persentase reduksi laju kebocoran sesuai dengan Tabel 8 yaitu sebanyak 20\%. Maka didapat nilai luas daerah berbahaya dan daerah dengan konsekuensi kebakaran dapat dilihat pada Tabel 9.

Tabel 8. Laju kebocoran setelah reduksi berdasar mitigasi

\begin{tabular}{|c|c|c|c|c|}
\hline No. & Komponen & $\begin{array}{l}\text { Ukuran } \\
\text { lubang }\end{array}$ & $\begin{array}{c}\text { Laju } \\
\text { Kebocoran }\end{array}$ & $\begin{array}{c}\text { Laju } \\
\text { Kebocoran } \\
\text { Setelah } \\
\text { Direduksi }\end{array}$ \\
\hline \multirow{4}{*}{1} & \multirow{4}{*}{$\begin{array}{l}\text { Pipa Gas Lurus KP 09+012 } \\
\text { Ø 14” }\end{array}$} & $1 / 4$ in & 2,860610118 & 1,716366 \\
\hline & & 1 in & 45,76976188 & 27,46186 \\
\hline & & 4 in & 732,3161902 & 439,3897 \\
\hline & & rupture & 6590,845711 & 3954,507 \\
\hline \multirow{4}{*}{2} & \multirow{4}{*}{$\begin{array}{l}\text { Pipa Gas Lurus KP } 15+110 \\
\varnothing 14 ”\end{array}$} & $1 / 4$ in & 2,860610118 & 1,716366 \\
\hline & & 1 in & 45,76976188 & 27,46186 \\
\hline & & 4 in & 732,3161902 & 439,3897 \\
\hline & & rupture & 6590,845711 & 3954,507 \\
\hline \multirow{4}{*}{3} & \multirow{4}{*}{$\begin{array}{l}\text { Pipa Gas Lurus KP } 19+040 \\
\varnothing 14 ”\end{array}$} & $1 / 4$ in & 2,860610118 & 1,716366 \\
\hline & & 1 in & 45,76976188 & 27,46186 \\
\hline & & 4 in & 732,3161902 & 439,3897 \\
\hline & & rupture & 6590,845711 & 3954,507 \\
\hline
\end{tabular}

Tabel 9. Nilai Flamable consequence

\begin{tabular}{|c|c|c|c|c|c|}
\hline No. & Komponen & $\begin{array}{l}\text { Ukuran } \\
\text { lubang }\end{array}$ & $\begin{array}{c}\text { Fraksi } \\
\text { frekuensi } \\
\text { kerusakan } \\
\text { generik }\end{array}$ & $\begin{array}{c}\text { Luas Daerah } \\
\text { Berbahaya } \\
\left(\mathrm{ft}^{2}\right)\end{array}$ & $\begin{array}{c}\text { Konsekuensi } \\
\text { kebakaran } \\
\left(\mathrm{ft}^{2}\right)\end{array}$ \\
\hline \multirow{3}{*}{1} & \multirow{3}{*}{$\begin{array}{l}\text { Pipa Gas Lurus KP } \\
09+012 \text { Ø 14" }\end{array}$} & $1 / 4$ in & 0,26143 & 184,764363 & 48,30440863 \\
\hline & & $1 \mathrm{in}$ & 0,65359 & 2645,899794 & 1729,34627 \\
\hline & & 4 in & 0,06535 & 4659,469947 & 304,5405194 \\
\hline $\mid$ & & rupture & 0,01960 & 20308,55373 & 398,2069359 \\
\hline \multirow{4}{*}{2} & \multirow{4}{*}{$\begin{array}{l}\text { Pipa Gas Lurus KP } \\
15+110 \varnothing 14 \text { " }\end{array}$} & $1 / 4$ in & 0,26143 & 184,764363 & 48,30440863 \\
\hline & & $1 \mathrm{in}$ & 0,65359 & 2645,899794 & 1729,34627 \\
\hline & & 4 in & 0,065359 & 4659,469947 & 304,5405194 \\
\hline & & rupture & 0,019607 & 20308,55373 & 398,2069359 \\
\hline \multirow{4}{*}{3} & \multirow{4}{*}{$\begin{array}{l}\text { Pipa Gas Lurus KP } \\
19+040 \varnothing 14 "\end{array}$} & $1 / 4$ in & 0,26143 & 184,764363 & 48,30440863 \\
\hline & & 1 in & 0,65359 & 2645,899794 & 1729,34627 \\
\hline & & 4 in & 0,065359 & 4659,469947 & 304,5405194 \\
\hline & & rupture & 0,26143 & 20308,55373 & 398,2069359 \\
\hline
\end{tabular}




\section{HASIL PERHITUNGAN}

Maka didapatkan hasil perhitungan kemungkinan kegagalan dan konsekuensi kegagalan dapat dilihat pada Tabel 10 dan Tabel 11. Didapat bahwa kondisi setiap pipa pada risk matrix berada pada posisi 1c dengan kategori medium seperti pada Gambar 3.

Tabel 10. Probability of Failure Setiap Pipa

\begin{tabular}{|l|l|c|c|c|c|c|}
\hline No & \multicolumn{1}{|c|}{$\begin{array}{c}\text { General } \\
\text { Failure } \\
\text { Frequency } \\
(g f f)\end{array}$} & $\begin{array}{c}\text { Damage } \\
\text { factor } \\
(D f(\mathrm{t}))\end{array}$ & $\begin{array}{c}\text { Management } \\
\text { System } \\
\text { Factor }(F m s)\end{array}$ & PoF & Kategori \\
\hline 1 & $\begin{array}{l}\text { Pipa Gas Lurus KP } \\
09+012 \text { Ø 14" }\end{array}$ & $3,068 \times 10^{-5}$ & 263,892 & 0,158489319 & $\begin{array}{c}0,0012798 \\
14\end{array}$ & 1 \\
\hline 2 & $\begin{array}{l}\text { Pipa Gas Lurus KP } \\
15+110 \varnothing 14 ”\end{array}$ & $3,06 \times 10^{-5}$ & 261,292 & 0,158489319 & $\begin{array}{c}0,0012672 \\
05\end{array}$ & 1 \\
\hline 3 & $\begin{array}{l}\text { Pipa Gas Lurus KP } \\
19+040 \varnothing 14 ”\end{array}$ & $3,06 \times 10^{-5}$ & 261,392 & 0,158489319 & $\begin{array}{c}0,0012676 \\
9\end{array}$ & 1 \\
\hline
\end{tabular}

Tabel 11. Consequence of Failure Setiap Pipa

\begin{tabular}{|c|l|c|c|}
\hline No. & \multicolumn{1}{|c|}{ Komponen } & $\begin{array}{c}\text { Luas daerah } \\
\text { kegagalan total }\left(\mathrm{ft}^{2}\right)\end{array}$ & $\begin{array}{c}\text { Kategori } \\
\text { konsekuensi }\end{array}$ \\
\hline 1 & $\begin{array}{l}\text { Pipa Gas Lurus KP 09+012 Ø } \\
14 "\end{array}$ & 2480,398134 & $\mathrm{C}$ \\
\hline 2 & $\begin{array}{l}\text { Pipa Gas Lurus KP 15+110 Ø } \\
14 "\end{array}$ & 2480,398134 & $\mathrm{C}$ \\
\hline 3 & $\begin{array}{l}\text { Pipa Gas Lurus KP 19+040 Ø } \\
14 "\end{array}$ & 2480,398134 & $\mathrm{C}$ \\
\hline
\end{tabular}

\section{Perencanaan Inspeksi}

Untuk mengetahui jenis inspeksi yang baik digunakan untuk menjaga keandalam pipa kedepannya perlu diketahui nilai sisa umur pipa terlebih dahulu, yakni dapat dilihat pada Tabel 12. Untuk menentukan metode inspeksi yang tepat adalah dengan melihat mekanisme kerusakan yang terjadi. Pada analisis kali ini, alat mengalami kerusakan berupa thinning yaitu penipisan ketebalan dinding alat akibat adanya korosi internal (internal corrossion). 


\section{Consequence Of Failures}
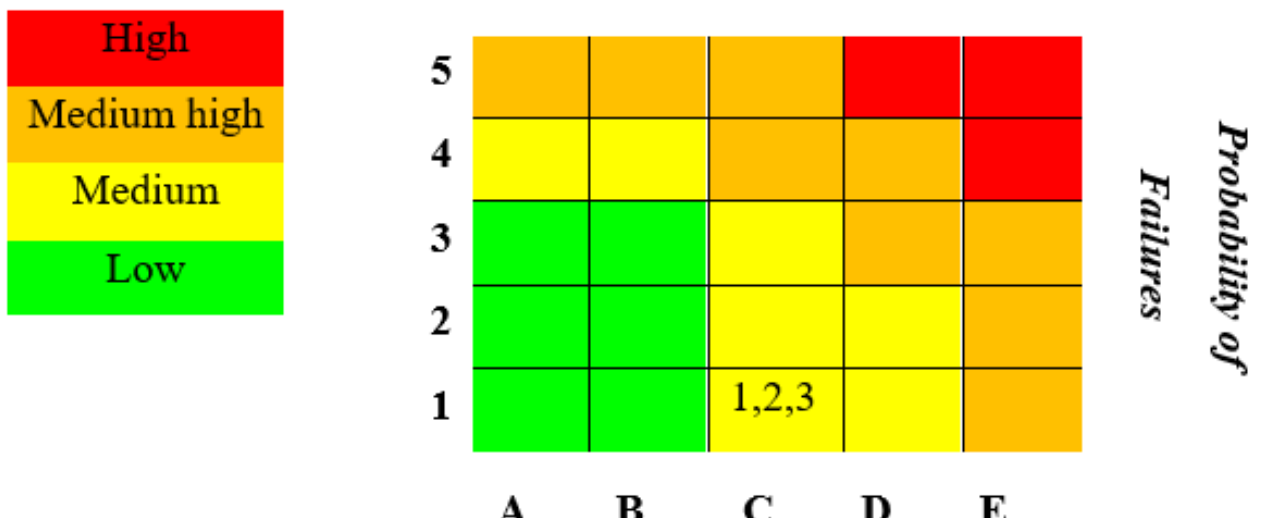

Gambar 3. Matriks Risiko

Tabel 12. Sisa Umur pipa

\begin{tabular}{|c|l|c|c|c|c|}
\hline No. & \multicolumn{1}{|c|}{ Komponen } & $\begin{array}{c}\mathrm{T}_{\text {act }} \\
\text { (in) }\end{array}$ & $\begin{array}{c}\mathrm{T}_{\text {min }} \\
\text { (in) }\end{array}$ & $\begin{array}{c}\text { CR } \\
\text { (in/tahun) }\end{array}$ & $\begin{array}{c}\text { remaining life } \\
\text { (tahun) }\end{array}$ \\
\hline 1. & $\begin{array}{l}\text { Pipa Gas Lurus KP 09+012 } \\
14 ”\end{array}$ & 0,255 & 0,176 & 0,005 & 15,8 \\
\hline 2. & $\begin{array}{l}\text { Pipa Gas Lurus KP 15+110 Ø } \\
14 ”\end{array}$ & 0,256 & 0,176 & 0,005 & 16 \\
\hline 3. & $\begin{array}{l}\text { Pipa Gas Lurus KP 19+040 Ø } \\
14 ”\end{array}$ & 0,255 & 0,176 & 0,005 & 15,8 \\
\hline
\end{tabular}

Beberapa metode yang dapat digunakan yaitu visual examination, ultrasonic straight beam, eddy current, flux leakage, radiography dan dimensional measurement (Wipri Alma, 2013). Metode-metode tersebut merupakan metode yang paling efektif digunakan untuk jenis kerusakan thinning. Selain itu, metode di atas merupakan jenis NDE (Non-Destructive Examination) yaitu inspeksi yang dapat dilakukan tanpa mengganggu proses produksi.

Berdasarkan hasil analisa resiko di atas maka integritas inspeksi dapat dilihat pada Tabel 13. Berdasarkan hasil dari matriks risiko yang menunjukkan bahwa tingkat risiko komponen Pipa Gas Lurus KP 09+012, KP 15+110, KP 19+040 Ø 14” berada pada tingkat medium risk dan sisa umur pakai komponen adalah 15,8 tahun, maka kita dapat menentukan strategi perencanaan inspeksi selanjutnya yaitu inspeksi dilakukan 36 bulan (3 tahun) sekali menggunakan metode External NDT. Inspeksi tersebut harus dilaksanakan sebelum komponen mencapai umur setengah dari Remaining Life yaitu 11 tahun 9 bulan yaitu pada tahun 2021 . 
Tabel 13. Integritas Inspeksi pada Peralatan Statis RBI (API,2008)

\begin{tabular}{|c|c|c|}
\hline No & Level Risiko & Jenis Inspeksi \\
\hline \multirow{2}{*}{1} & \multirow{2}{*}{ High } & Internal Entry \\
\cline { 3 - 3 } & & External $N D T$ \\
\hline 2 & Medium & Internal Entry \\
\hline No & Level Risiko & Jenis Inspeksi \\
\hline 2 & \multirow{2}{*}{ Medium } & External NDT \\
\hline \multirow{2}{*}{3} & \multirow{3}{*}{ Low } & Limited Internal Inspections \\
\cline { 3 - 3 } & & Internal Entry \\
\cline { 3 - 3 } & & External NDT \\
\cline { 3 - 3 } & &
\end{tabular}

Tabel 14. Hasil Uji Tingkat Kekritisan untuk Tipe Kegagalan (API,2008)

\begin{tabular}{|c|c|c|c|c|}
\hline $\begin{array}{c}\text { Probability } \\
\text { of Failure }\end{array}$ & $\begin{array}{c}\text { Consequences } \\
\text { of Failure }\end{array}$ & $\begin{array}{c}\text { Metode } \\
\text { Inspeksi }\end{array}$ & $\begin{array}{c}\text { Frekuensi } \\
\text { Inspeksi (bulan) }\end{array}$ & $\begin{array}{c}\text { Luas Area } \\
\text { Inspeksi }\end{array}$ \\
\hline High & High & U.T & 12 & Penuh \\
\hline High & Medium & U.T & 12 & Parsial \\
\hline High & Low & U.T & 12 & Kecil \\
\hline Medium & High & U.T & 24 & Penuh \\
\hline Medium & Medium & U.T & 30 & Parsial \\
\hline Medium & Low & U.T & 30 & Kecil \\
\hline Low & High & U.T & 30 & Penuh \\
\hline Low & Medium & U.T & 36 & Parsial \\
\hline Low & Low & U.T & 48 & Kecil \\
\hline
\end{tabular}

\section{KESIMPULAN}

Berdasarkan hasil penelitian yang telah dilakukan maka dapat diambil beberapa kesimpulan, diantaranya adalah sebagai berikut:

1. Berdasarkan analisis RBI terhadap 3 lokasi didapatkan Probability of Failure untuk KP 09+012 senilai 0,001279814 , KP $15+110$ senilai 0,001267205 , dan KP 19+040 senilai 0,00126769. Untuk nilai prediksi luas daerah kegagalan Consequence of Failure pada KP 09+012 senilai 2480,398134, KP $15+110$ senilai 2480,398134, KP 19+040 senilai 2480,398134. keadaan pipa ditiap lokasi termasuk POF kategori 1, dan COF kategori C.

2. Berdasarkan analisis penentuan sisa umur, sisa umur pipa KP 09+012 senilai 15,8 tahun, pipa KP 15+110 senilai 16 tahun, pipa KP 19+040 senilai 15,8 tahun. Sisa umur dihitung dari inspeksi dilakukan yakni dari tahun 2018. 
3. Interval inspeksi ditentukan berdasarkan uji tingkat kekritisan yakni kategori medium Risk dimana inspeksi selanjutnya dilakukan 36 bulan sekali sebelum mencapai setengah remaining life time dengan menggunakan metode External NDT.

4. Metode inspeksi yang dianjurkan berupa pemeriksaan visual examination, ultrasonic straight beam, eddy current, flux leakage, radiography dan dimensional measurement.

\section{DAFTAR PUSTAKA}

,. 2008. American Petroleum Institute (API) 581 Risk Based Inspection Base Resource Document. Washington, D.C: API Publishing Services.

Barjono, R.R.A., 2010. Kajian Risiko Sistem Perpipaan Di Wilayah Padat Penduduk Berdasarkan Metode Indeks Dan API 581 Studi Kasus: Pipa Transmisi Gas TambunTegal Gede. Institut Teknologi Bandung..

Menteri Pertambangan dan Energi Republik Indonesia, 1997. Keselamatan Kerja Pipa Penyalur Minyak dan Gas Bumi, Indonesia.

Mobin, 2018 Penilaian Tingkat Risiko Pipa Penyalur Menggunalan Metode Kombinasi Analytical Network Process (ANP) - Risk Based Inspection Di PT.X.

Noori, S.A. dan Price, J.W.H., 2006. A risk approach to the management of boiler tube thinning. Nuclear Engineering and Design, 236(4), pp.405-414.

Perumal, K.E., 2014. Corrosion Risk Analysis , Risk Based Inspection and a Case Study Concerning a Condensate Pipeline. Procedia Engineering, 86, pp.597-605.

Prayogo, G.S., 2015. Analisis Risiko Heat Recovery Steam Generator Dengan Metode Risk Based Inspection Semi Kuantitatif, API 581.

Verdana, A., 2010. Penentuan Jenis dan Waktu Inspeksi Pipa Penyalur Gas Berdasarkan Tingkat Risiko Studi Kasus: Pipa Transmisi Gas Suban-Grisik, 